IRSH 62 (2017), Special Issue, pp. I65-190 doi:I0.1017/So02085901 7000608 (C) 2018 Internationaal Instituut voor Sociale Geschiedenis

\title{
World War II and Brazilian Workers: Populism at the Intersections between National and Global Histories
}

\author{
ALEXANDRE FORTES \\ Universidade Federal Rural do Rio de Janeiro \\ Department of History \\ Av Governador Roberto da Silveira $S / N$ \\ Nova Iguaçu, RJ, Brazil \\ E-mail: fortes.ufrrj@gmail.com
}

\begin{abstract}
This article argues that World War II played a very important, and generally underestimated role in the rise of Brazilian populism. It starts with an overview of recent trends in the debates on the use of the concept of populism in Brazil, with particular attention to works that stress the years from I94 I to I945 as a critical juncture. Secondly, it explores the connections between war effort, changes in labor regulations, and workers' political participation in different contexts. Finally, it summarizes how the economic and social effects produced by the involvement of Brazil in the War led to profound and accelerated changes in the nature of the regime of Getúlio Vargas and in the role of workers in Brazilian politics.
\end{abstract}

Populism is one of the most controversial terms in our political vocabulary. Used to describe a broad range of phenomena and bearing strong pejorative undertones, numerous scholars have questioned the concept. Attempts to discard it, however, have been in vain. The term re-emerges with each inflection of the global political scene, whether on the left, with the election of progressive governments in South America in the first decade of the twenty-first century, ${ }^{\mathrm{I}}$ or on the right, in our current moment, epitomized by the election of Donald Trump as president of the United States. ${ }^{2}$

Although the transnational character of these "populist waves" is selfevident, analyses of them generally echo the nationalist logic inherent in the

I. See, for example, the polemic between Laclau and Žižek: Ernesto Laclau, On Populist Reason (London [etc.], 2005); Slavoj Žižek, "Against the Populist Temptation", Critical Inquiry, 32:3 (2006), pp. $55 \mathrm{I}-574$.

2. For recent examples of two significantly different points of view, see: Christian Salmon, "Trump, Fascism, and the Construction of 'The People': An Interview with Judith Butler", available at: http://www.versobooks.com/blogs/3025-trump-fascism-and-the-construction-ofthe-people-an-interview-with-judith-butler; last accessed 24 October 20I7; Guillaume Erner, "Europe: The Return of the People, or of Populism. Interview with Jacques Rancière", available at: http://www.versobooks.com/blogs/2896-europe-the-return-of-the-people-or-of-populism; last accessed 24 October 2017. 
object of study. Global processes, such as the impact of the Great Depression in the I930s or the reaction to the social impact of globalization in the post-1989 era, are usually mentioned, and studies of populism often identify general, shared characteristics of the phenomenon. The study of each case, however, tends to prioritize domestic factors.

This article will probe this subject from a different perspective, analyzing Brazil's major historical experience of populism, varguismo, through the lens of country's involvement in World War II. The reign of Getúlio Vargas (I 882I954), the wealthy Brazilian rancher who was twice elected president and also ruled as a dictator from 1937 to 1945 under the so-called Estado Novo, I hypothesize, established a form of mass politics that can only be fully understood when taking the geopolitical, economic, and social impact of the most extensive armed conflict in the twentieth century into account. Thus, it will be possible to bring the subject of populism together with the debate concerning the relationship between total war and the period's transformations in social rights and labor relations. This article aims to illustrate how an attentive eye toward the relationship between national space and global processes can substantially alter the contours of a traditional object of study.

This article has three parts. First, I consider the relationship between workers, varguismo, and the historiographic debate about the validity of the use of the concept of populism in the Brazilian context. Next, the article will engage with scholarship that discusses the relationship between total war, citizenship, and social policies in other regions. In the third part, I pause to consider the significance of World War II in creating the conditions for the reconfiguration of the working class and in its formative role in Brazilian workers' political experience.

\section{VARGAS, WORKERS AND POPULISM}

In studies of twentieth-century Brazil, populism has been approached from many angles, yet one of the major concerns has always been to understand the ways in which workers were incorporated into political participation from the I930s on. That is to say: why did so many workers support a political regime that, at least in the eyes of many academic observers, did not genuinely represent their interests? Although the adjective "populist" can be applied to a diverse spectrum of types of leadership, parties, and local governments, at the center of the debate over the validity of the concept is the final assessment of the political legacy of Getúlio Vargas's rule and that of his political heir, president João Goulart (196I-I964). ${ }^{3}$

3. Originally from the state of Rio Grande do Sul on the border with Argentina and Uruguay, Vargas ran in the presidential election of 1930 with the Liberal Alliance (Aliança Liberal), a coalition of regional oligarchies from the peripheries of Brazil that had the broad support of the 
In the I960s and I970s, authors like Gino Germani, Otávio Ianni, and Francisco Weffort used the concept of populism to construct a general model used to explain the transformations unfolding in Latin America from the I930s on, particularly in the three most iconic cases: the reigns of Lázaro Cárdenas in Mexico (1934-1940), Juan D. Perón in Argentina (1943/45-1955), and Getúlio Vargas in Brazil (1930-1945; 195I-1954). ${ }^{4}$ These approaches took as their point of departure the impact of the Great Depression on agro-export systems, the crisis of hegemony within Latin American societies, and working- and middle-class dissatisfaction with the region's oligarchical republics. These factors combined, the classical analyses said, brought about the ascendancy of illiberal ideas, the establishment of a new economic model (import substitution industrialization), the acceleration in internal migration, and the emergence of charismatic leaders whose ascent was based on the manipulation of the working classes, particularly what was seen, following Germani, as the new and "immature" sectors of the working class. In these approaches, populism always appeared as manipulative and demagogic, and workers as tempted to follow a deceptive leader.

Although it remains influential in public opinion, this model did not survive either the conceptual revisions or the increase of empirical research

middle classes in the country's main urban centers, of the low-ranking officer class in the Army that had led various rebellions in the I920s (the so-called lieutenants or tenentes) and of the reformists within the labor movement. The aliancistas (supporters of the Liberal Alliance) contested the monopoly of power held by politicians in the states of São Paulo and Minas Gerais since the beginning of the nineteenth century and defended the strengthening of centralized power, the adoption of policies that promoted industrialization, and the expansion of social legislation to avoid worsening labor conflicts. The candidate from the incumbent party, Júlio Prestes, was declared winner of the election, but before he could be sworn in as president, his government was overturned by a political-military movement that denounced the electoral results as fraudulent. Coming to power through this "Revolution of 1930", Vargas was proclaimed the head of the Provisional Government, and later elected the president of the Republic by indirect means through the National Constituent Assembly of 1934. In 1937, the presidential elections that had been planned for the following year were suspended, using as a pretext the supposed discovery of a communist conspiracy to take power. Instead, a dictatorial government known as the Estado Novo (New State) was installed, ushering in a corporatist regime that was one of the most authoritarian and ideologically most right-leaning of Latin America's "classical" populisms. It would last until 1945, when Vargas was deposed, beginning a period of electoral democracy. In 1950, Vargas became president of the Republic again, this time democratically elected, yet proving unable to withstand the pressure put on him by his opposition. In 1954, in the context of a crisis after a failed assassination attempt against his major political adversary, he committed suicide while still in office. The years after his death saw a continuation of many of the arrangements of varguismo. Taking office in 196I, President João Goulart, a left-wing nationalist, was about to renew the populist tradition in a more progressive and reform-oriented way. This was disrupted by a coup in 1964 , which ushered in a military dictatorship that lasted until 1985 .

4. Gino Germani, Política y sociedad en una época de transición. De la sociedad tradicional a la sociedad de masas (Buenos Aires, I962); Otávio Ianni, O colapso do populismo no Brasil (Rio de Janeiro, 1968); idem, A formação do estado populista na América Latina (Rio de Janeiro, 1975); Francisco Weffort, O populismo na política brasileira (Rio de Janeiro, 1978). 
on the worlds of labor and populism in Latin America, especially from the I980s on. Inspired by British Marxist historiography, the studies that made up the "Latin American labor studies boom" made it impossible to sustain that workers had been simply manipulated by the state or by leaders who represented the interests of other social classes. This revisionist historiography experienced an additional uplift in the r 990 s when the destructive influence of neoliberalism was also felt in Brazil. Latin America's populist regimes were re-evaluated in a newly positive light, because of their role in the construction of more sovereign national states, regulatory systems of labor relations, and of social welfare. Influential authors came to see in the concept of populism an abusive and derogatory generalization. Allan Knight, a distinguished historian of the Mexican Revolution, defended abandoning the term, which, in his view, was incapable of contributing to the analysis of cardenismo, the presidency of Lázaro Cárdenas in postrevolutionary Mexico, or of what he called "many cardenismos". ${ }^{6}$ In Brazil, the classic reference epitomizing the shifts in the debate was Ângela de Castro Gomes's The Invention of Laborism ( $A$ invenção do trabalhismo). ${ }^{7}$ Gomes, it should be stressed, did not concentrate on the early Vargas years after the so-called Revolution of 1930 and the first years of the Estado Novo, but rather on the period after I94I, when the Vargas regime started to open up to a more "mobilization"-oriented form of politics and stronger labor participation. She argued that the late Vargas era allowed, to a limited but momentous degree, for the inclusion of important parts of the working classes in the realm of politics and society, and enabled the labor movement to articulate a new notion of "social citizenship".

5. John French, “The Latin American Labor Studies Boom”, International Review of Social History, 45:2 (2000), pp. 279-308.

6. Alan Knight, "Cardenismo. Coloso o catramina?", in María Moira Mackinnon and Mario Alberto Petrone (eds), Populismo y neopopulismo en América Latina. El problema de la Cenicienta (Buenos Aires, 201 I [1998]), pp. 197-230.

7. Angela Maria de Castro Gomes, A invenção do trabalhismo (Rio de Janeiro [etc.], 1988). Just as with the word "labor" in English, the Portuguese adjective trabalhista and the noun trabalhismo, have a variety of connotations, referring, at times, to the world of labor broadly conceived (as in, legislação trabalhista, "labor legislation"), to the labor movement (as in manifestações trabalhistas, or "workers' demonstrations”), and also to the Brazilian Workers' Party, or the Partido Trabalhista Brasileiro (PTB), which was created by supporters of Vargas during the process of transition to democracy in 1945. In her analysis of the period between 194I and 1945, Gomes integrates these three dimensions of the concept of trabalhismo, inasmuch as the period begins with various initiatives of the Estado Novo seeking to lend more vitality to the state-run labor union structure, moves on to the passing of Consolidation of Labor Laws (Consolidação das Leis do Trabalho ) in I943, and draws to a close with the creation of the PTB. Despite the relevance and originality of Gomes's book, her approach carries numerous risks, particularly when she fails to recognize the role of other political forces acting on labor during that period, such as the communists, thus potentially obscuring workers' agency. 
It was only in the mid-1990s, however, that Gomes openly argued for the abandonment of the concept of populism, whose diffusion in Brazil, she claims, resulted from the work of a group of intellectuals in the mid-r95os, which set out to systematize what were essentially the prejudices of a liberal-conservative elite against the incorporation of the "inorganic popular sectors" into politics. ${ }^{8}$ In a similar vein, Marxist-inspired interpretations during the I 960 and I 970 s associated populism with the supposed structural weaknesses of the Brazilian working class, which made it vulnerable to a political force alien to it, or with the mistakes made by their organizations and leadership. In contrast to this, for Gomes (and many other revisionists), it would be more appropriate to interpret Brazilian populism, particularly the period from 1945 to 1964 , i.e. after the first, mostly dictatorial reign of Getúlio Vargas, as a kind of "labor pact", a notion that describes a relationship between "unequal actors" based on the state's concession of material and symbolic benefits and their reception and interpretation by workers, "following the terms of their possibilities and experiences".?

Among those who contributed to this revisionist reading, criticism of the concept of populism quickly evolved into a vindication of the laborism of Vargas supporters. For Daniel Aarão Reis Filho, the "laborist tradition" (by which he means the whole period between I930 and 1964) was the Brazilian variant of the Latin American "national-statist traditions", which the labor movement had embraced from Juan Perón to Fidel Castro. As part of this "tradition", workers' strikes and demonstrations were "sometimes protected and encouraged, sometimes contained, and even repressed, depending on the conjunctures and the governments" then ruling the country. ${ }^{1 \circ}$ Jorge Ferreira, for his part, understands what is traditionally called "populism" as a "laborist project", in which "the state and the working class identified common interests". ${ }^{\mathrm{I}}$

Removing the concept of populism from this scene, as pejorative, imprecise, and ideologically contaminated as it is, we would be left with the extraordinarily broad and comprehensive notion of trabalhismo, i.e. a certain kind of labor activism that emerged in the mid-twentieth century and overlapped with populism. As explained above, for authors such as Ferreira and Aarão, the phenomenon refers simultaneously to a pact

8. These intellectuals formed in 1952 as the "Itatiaia Group" and were sponsored the Ministry of Agriculture. Angela Maria de Castro Gomes, "O populismo e as ciências sociais no Brasil. Notas sobre a trajetória de um conceito”, Tempo, I:2 (1996), pp. 3 I-58.

9. Ibid., pp. $5 \mathrm{I}-54$.

Io. Daniel Aarão Reis Filho, "O colapso do colapso do populismo ou a propósito de uma herança maldita”, in Jorge Ferreira (ed.), O populismo e sua história. Debate e crítica (Rio de Janeiro, 200I), pp. 319-377, 346.

I I. Jorge Ferreira, "O nome e a coisa. O populismo na política brasileira”, in Ferreira, O populismo e sua história, pp. 59-1 24, 103. 
between workers and the state that expresses a particular form of class consciousness, yet also to a "tradition" that connects legal, welfare, union, and party structures to social mobilization (simultaneously combining contention from below and repression from above). Above all, however, trabalhismo involves charismatic leaders who are able to "express" the interests, beliefs, and values of their base.

The research of Gomes and others who have questioned the very notion of populism has been incorporated into recent international scholarship on Brazil. Oliver Dinius, for instance, taking the specificities of the reality of the steel-producing city of Volta Redonda, classifies trabalhismo during the Vargas era as a mere variation of "Catholic paternalism". ${ }^{{ }^{2}}$ While suggestively pointing to the intricate relationship between the state and the Church during the Vargas years, such an analysis also illustrates the risk of separating trabalhismo from the wider dynamics of populism in Brazil: It should not be forgotten that Getúlio Vargas was an avowed agnostic, who named his first son with the decidedly un-Catholic name Lutero and, moreover, for whom one of the main achievements of his trabalhista politics was to avoid the formation of a confessional form of unionism in a country deeply shaped by Catholicism. That does not mean that religion was absent from politics during varguismo: As an older but very nuanced analysis of the role of religiosity during varguismo has demonstrated, the process of the construction of a popular base of Vargas supporters involved the channeling of popular religious feelings toward the state, by way of the development of a form of civic ritualism and a cult of the figure of the dictator. ${ }^{13}$

The trend to completely shun the concept of populism soon revealed further limitations. For instance, one of the characteristics of revisionist approaches is that it is fully based on "methodological nationalism". ${ }^{14}$ The earlier sociological scholarship of the I960s and I970s had many blind spots, yet it was able to conceive the phenomenon as a continental one, thinking of Latin America as a collection of units generated by common historical processes and exposed to the same general conditions, within which similar processes were taking place. While this earlier research also proceeded to move on to the national level in the next step of its analyses (once formed, populisms evolved according to their respective national contexts and the peculiarities of their leaderships), the posterior revisionist approaches were much more limited in that regard. They tend to highlight each nation's specificities in such a way as to discard in advance the very

I 2. Oliver Dinius, Brazil's Steel City: Developmentalism, Strategic Power, and Industrial Relations in Volta Redonda, 194I-I964 (Stanford, CA, 2010), pp. 72-76.

I 3. Alcir Lenharo, Sacralização da política (Campinas, I986).

I4. For a critique of "methodological nationalism" in labor history, see Marcel van der Linden, Workers of the World: Essays toward a Global Labor History (Leiden [etc.], 2008), pp i 5-16. 
possibility of comparative analysis or the production of conclusions that might extrapolate the limits of the nation state.

Furthermore, the substitution of populism for trabalhismo impedes the very understanding of the diversity of processes through which workers have been incorporated into Brazilian politics during that period. In São Paulo, for instance, this process of inclusion originated in the mass support of two local politicians rather than Vargas himself, Ademar de Barros and Jânio Quadros, ${ }^{\text {IS }}$ leaders of movements that, as John French explains, were essentially anti-trabalhista and anti-Vargas. Such phenomena indicate, that trabalhismo and populism had many overlaps, yet were by no means identical. French proposes taking a different path, one based on an interactive model of social class. Analyzed in such a way as to integrate the changes in the internal composition of the working class with the transformation that other social segments of Brazil's population (like the middle class) experienced, the author emphasizes the importance of interclass alliances, which, he insists, imply neither passivity, nor subordination of workers to charismatic leaders. These alliances would form the basis for a "populist political system". Similarly, in the analysis of Fernando da Silva and Hélio da Costa, rather than a "blind and active adherence" to populist politics, workers exercised "a pragmatic realism with an elevated sense of the calculus needed to weigh the possible gains and benefits", imposing "on the state and on their bosses concessions and duties by way of a language drawn from their own populist rhetorical resources". ${ }^{16}$

"Populism" cannot serve us as a self-sufficient conceptual instrument. Equally, the term should not be discarded in the name of the irreducible singularity of every individual political phenomenon. The explanatory capacity of this concept must be tested by analyzing the phenomena it describes as historical processes. Thus, the analysis of specific and contextually embedded mutations can be more productive than the search for essential characteristics. In the Brazilian case, a fundamental point of departure for this type of approach is, for instance, a differentiation between the lasting impact of the Vargas era, especially on labor, on the one hand, and the trajectory of varguismo as a political movement, on the other. It is a matter of general agreement among specialized scholars that the fifteen years of the first Getúlio Vargas government (1930-1945) set the basic

I 5. "Pensar a América Latina. Entrevista de Daniel James e John French", in Alexandre Fortes et al. (eds), Na luta por direitos. Estudos recentes em história social do trabalho (Campinas, I999), pp. I89-196, I9I; John D. French, The Brazilian Worker's ABC. Class Conflict and Alliances in Modern São Paulo (Chapel Hill, NC, I992), pp. 199-224. For São Paulo, see also Paulo Fontes and Adriano Duarte, "O populismo visto da periferia. Adhemarismo e janismo nos bairros da Mooca e São Miguel Paulista (1947-I953)”, Cadernos AEL, I I:20/2 I (2004), pp. 83-I 2 I.

16. Fernando Teixeira da Silva and Hélio da Costa, "Trabalhadores Urbanos e Populismo. Um Balanço dos Estudos Recentes”, in Ferreira, O populismo e sua história, pp. 205 -271, 225. 
framework for modern Brazil: a largely urban, semi-industrialized country with a strong nationalist culture and a comparatively independent foreign policy, in which the national state played an important role in both economic and social policy. The long-term survival of the country's system of labor relations that Vargas established still intrigues most analysts. It remained untouched after the dictator's fall in I 945, was reinforced when he returned as a democratically elected president five years later, remained in place after a military coup removed João Goulart from power in 1964, and suffered only minor changes when a new democratic constitution was promulgated in I988. With the same basic features, it remains in place even after enduring fierce attacks by the neoliberal governments during the I990s that promised to overcome the "Vargas legacy". As an organized political force, however, the Vargas phenomenon did not have the same level of endurance or consistency (in sharp contrast, for instance, with Peronism in Argentina where the movements is a major political actor up until today): Vargas governed for fifteen years without creating a political party or a general workers' confederation. When the transition to democracy became imminent in 1945 , the dictator initially attempted to organize a workers' wing of the recently created Social Democrat Party (Partido Social Democrático, or PSD), which was led by rural oligarchs. The government supporters inside the labor movement and central figures of the social policies of the Estado Novo dictatorship (a group that included staff of the Ministry of Labor and members of the political police) revolted against this solution, eventually resulting in the formation of the Brazilian Labour Party (PTB). ${ }^{17}$ Once deposed, Vargas entered into post-war electoral politics in the ambiguous position of honorary president of both of these two parties.

The intensification of political conflicts that brought on the political crisis of Vargas's second administration (ultimately leading the president to commit suicide in 1954) further accelerated profound changes in the PTB's orientation and identity. The party assumed a more radical and anti-imperialist position, in an intricate process of approximation with the communists. ${ }^{18}$ The attempt to maintain some measure of programmatic

17. For an analysis of how this process played out in Rio Grande do Sul (one of the regional strongholds of varguismo), see Jorge Ferreira, "Sindicalismo, política e trabalhismo no Rio Grande do Sul. A trajetória de José Vecchio”, in Daniel Aarão Reis Filho (ed.), Intelectuais, história e política. Séculos XIX e XX (Rio de Janeiro, 2000), pp. I82-2 I 8.

I8. For a general overview of the PTB's development in those years, see Lucilia Delgado de Almeida Neves, PTB, do getulismo ao reformismo, 1945-1964 (São Paulo, 1989). The regional dynamics again in Rio Grande do Sol are analysed in Miguel Bodea, Trabalhismo e populismo no Rio Grande do Sul (Porto Alegre, 1992). The Communist Party of Brasil (Partido Comunista do Brasil, PCB) had experienced only a brief (but politically very successful) period of legal existence from 1945 until 1947 when it was driven underground again. However, it continued to exert a major influence both on the union movement and intellectual life during the 1950 and early 1960s. 
and organizational cohesion among Vargas's political heirs, however, did not survive the effects of the long dictatorship installed in Brazil in I964. When political amnesty declared in 1979 set in motion the process of redemocratization, the PTB remained under the control of Vargas's conservative niece, Ivete Vargas. Another contender for Vargas's legacy, the former governor Leonel Brizola, saw himself as obliged to form a new political organization, the Workers' Democratic Party (Partido Democrático Trabalhista, or PDT). None of these parties, however, became a relevant channel for the political expression of Brazil's workers' movements. It was the new Workers' Party (Partido dos Trabalhadores, PT), that filled this role after I980, a party whose leaders had, since the I970s, stood up against the corporatist union structure that had been created during the Vargas era, creating the more participatory New Unionism, and who strove for their own representation in the electoral system without the mediation of professional politicians. ${ }^{19}$

Vargas's legacy, then, has traveled along several trajectories and reveals a particularly sharp contrast between the impact of its specific way of regulating the relations between labor, capital, and the state, on the one hand, and of its political movement, on the other. These two trajectories are also telling because they imply a marked dissonance between the innovative agenda of the "revolutionaries of 1930" (industrialization, labor legislation, strengthening of centralized power, and so on $)^{20}$ and the conservatism of their political methods: In the first decade of Vargas's rule, the regime made no effort to mobilize the masses of workers. ${ }^{21}$ On the contrary, it was more Vargas's adversaries who had to resort to popular mobilization, particularly in the three most important attempts to overturn him: the so-called Constitutionalist Revolution of 1932 in São Paulo; ${ }^{22}$ the insurrectionary movement of the National Liberation Alliance (Aliança Nacional Libertadora), led by the communist Luís Carlos Prestes, in $1935 ;^{23}$ and the attempted coup carried out by Brazilian fascists who were part of the group Brazilian Integralist Action (Ação Integralista Brasileira) in $1938 .{ }^{24}$

19. Margareth Keck, “The New Unionism in the Brazilian Transition”, in Alfred Stepan (ed.), Democratizing Brazil: Problems of Transition and Consolidation (New York, 1989), pp. 252-296. 20. On the "Revolution of 1930 " and the role of socialists in the early Vargas years also the contribution by A.S. Castellucci and Benito Bisso Schmidt in this Special Issue.

2I. Except if we consider the civic commemorations that the regime promoted as mass mobilizations. Maria Helena Capelato, Multidões em cena. Propaganda politica no varguismo e no peronismo (São Paulo, I998), pp. 5 I-72.

22. Barbara Weinstein, The Color of Modernity: São Paulo and the Making of Race and Nation in Brazil (Durham, NC, 2015), ch. 3, “The Middle Class in Arms? Fighting for São Paulo".

23. Anita Prestes, Luiz Carlos Prestes e a Aliança Nacional Libertadora. Os caminhos da luta antifascista no Brasil, 1934/35 (Petrópolis, 1997).

24. Hélgio Trindade, Integralismo. O fascismo brasileiro na década de 30 (São Paulo, 1979). 
If we consider the incorporation of the masses as one of the main political resources characteristic for populist regimes, then it is the historical conjuncture of World War II that functioned as an initial moment of a metamorphosis in the political movement around Vargas. While several authors have remarked on the qualitative changes of the interrelation between the Brazilian workers' and the Estado Novo in the period from I 940 to I 943 , these shifts have generally been understood as the result of a natural evolution arising from the progressive application of corporatist doctrines or as a reaction to changes in the domestic political scene. ${ }^{25}$ Contrary to such an "internal" view, this article argues that it was Brazil's growing involvement in the global conflict that played the most decisive role in these changes. This manifested itself in two processes in particular: On the one hand, the war effort and the alliance with the United States created the conditions that set in motion a cycle of industrialization and diversification of economic activity in Brazil, which, in turn, generated important changes in the composition of the working class. On the other, episodes of aggression by the Axis forces mobilized nationalist sentiment, which gave rise to a new political dynamic that led both supporters and adversaries of the regime, including communists, to take to the streets, presaging the post-war democratic era to come. ${ }^{26}$ The way in which Vargas and his supporters dealt with the economic, social, and political impact of Brazil's insertion in this critical global context helps us to understand the aforementioned paradox between the strength and longevity of the institutional legacy of the Vargas era and its comparatively lesser success in terms of political movement. The exceptional situation that the war created helped consolidate a form of national politics centered around the industrialization of the country and the corporatist system of labor relations. Yet, the reactive, belated character of Vargas's initiatives to promote mass politics created a political legacy that was both precarious and contradictory. Before developing these arguments examining the particularities of Brazil's insertion in the context of World War II, I will

25. See, for example, Luiz Werneck Vianna, Liberalismo e sindicato no Brasil (Rio de Janeiro, 1976); Armando Boito Junior (ed.), O sindicalismo de estado no Brasil. Uma analise crítica da estrutura sindical (Campinas, I99I).

26. I have analyzed elsewhere in a more detailed way the complex dynamic behind the wave of insurrections that swept the country from the North to the South in reaction to the sinking of Brazilian ships by German submarines (with Vargas supporters at the forefront and the communists involved clandestinely), especially on the night of I8 August 1942, resulting in the destruction of German, Japanese, and Italian companies, residences, and clubs and those of the descendants of these immigrant groups. Alexandre Fortes, "A espionagem Aliada no Brasil durante a segunda guerra mundial. Cotidiano e política em Belém na visão da inteligência militar norte-americana", Esboços. Revista do Programa de Pós-Graduação em História da UFSC, 22: 34 (2016), pp. 8 I-I I 5, I03-I09. 
briefly sketch the international historiographical debate on the relationship between total war, labor relations, and social rights.

\section{TOTAL WAR, CITIZENSHIP, AND SOCIAL POLICIES}

Historical scholarship dedicated to a wide variety of periods and countries has examined the role of the exceptional circumstances that war in general and the totalizing wars of the twentieth century create, both in strengthening the modern state's ability to regulate the economy and incorporating different sectors of the population, yet especially the lower classes as citizens. Hobsbawm attributes the very survival of the French Republic of I 792 to I 794 to the Jacobins' invention of what he calls "total war" (a notion that many other scholars would only use for the industrialized wars of the twentieth century): Surrounded by the most powerful armies in Europe, the French achieved victory by resorting to the "total mobilization of the nation's resources", obtained "through conscription, rationing and a rigidly controlled war economy, and virtual abolition, at home or abroad, of the distinction between soldiers and civilians". The state of war triggered the period's proactive popular action in support of the revolutionary government, whose methods "brought social justice nearer", even though it soon became clear the militarization of the police and of society were incompatible with "decentralized voluntarist direct democracy" that the sansculotterie cherished. ${ }^{27}$ Similar paradoxes repeatedly appeared in other historical contexts.

The US Civil War resulted in a further "radicalization" of war and represents one of the nineteenth-century armed conflicts that anticipated the total wars of the twentieth century, including a close connection between war, social policy, and citizenship. Theda Skocpol dedicated one of her most classic works to the analysis of a pioneering program that introduced generous social programs for elderly, disabled, and dependent citizens, which the federal government implemented during Reconstruction (I865-I 877). The competitive party politics of the late nineteenth century, which was the result of the expansion of suffrage, led to the expansion of benefits for veterans and their families. Expectations that this social policy would be implemented and universally applied, however, lost ground in the country's political agenda as the generation that had lived through the war disappeared by the turn of the twentieth century. ${ }^{28}$

In the twentieth century, especially in World War II, modern, industrialized war further morphed into total war, affecting and mobilizing societies comprehensively. This created space for interventionist policies,

27. Eric Hobsbawm, The Age of Revolution, $1789-1848$ (New York I 996 [1962]), p. 67.

28. Theda Skocpol, Protecting Soldiers and Mothers: The Political Origins of Social Policy in the United States (Cambridge, MA [etc.], 1992). 
even in political environments predominantly hostile to it, such as in the United States. John Kenneth Galbraith underscores that the resistance that Keynesian ideas met and the timidity of anti-cyclical measure taken during Franklin D. Roosevelt's first administration contributed to the fact that, as late as 1939, 9.5 million Americans (seventeen per cent) were still unemployed. US involvement in the war led to the multiplication of government spending and, in 1942, various sectors experienced labor shortages. Galbraith comments, speaking ironically, that Hitler "was the true protagonist of the Keynesian ideas". ${ }^{29}$ Yet, it was more than the state's full mobilization of the economy. Analyzing the context of labor union action of this period, Nelson Lichtenstein emphasizes that although "war-era corporatist structures failed to win lasting institutional expressions", in contrast with Western Europe, during the war, labor conflicts pointed toward other possibilities for the future:

[...] elite power at the top of the mobilization apparatus was repeatedly challenged by insurgencies from below that sought to take advantage of the unprecedented demand for labor while at the same time actualizing the pluralist, social-patriotic ethos that was the quasi-official ideology of the World War Two home front. ${ }^{30}$

Already during World War I, it became evident that the overwhelming demands created by the mobilization of millions of soldiers over numerous years and the volume of armaments and supplies used in combat stretched thin the labor force, thus giving industrial workers an exceptional lever, strengthening the unions, and generating waves of labor activism. The war also transformed the composition of the labor force, for example in incorporating women into industry.

Conceptions of political economy also changed when the great wars of the twentieth century ended what Karl Polanyi had called "a hundred years of peace". He pointed to the connection between the geopolitical "balance of power" mechanism, a self-regulating market, the liberal state, and the gold standard. ${ }^{3 \mathrm{I}}$ The rupture of the first of these pillars of the nineteenthcentury's global order shattered the others. Great Britain, bastion of fiscal equilibrium, was never the same again after having waged two wars that were well beyond the country's means. Centralized economic planning almost became a conditio sine qua non, as Lenin understood in extracting lessons from the German war economy that were then applied to the centralized economy policies in the Soviet Union during the period of Wartime Communism (I918-1921). While in I939 only Germany and the USSR

29. John Kenneth Galbraith, The Age of Uncertainty (Boston, MA, I977), p. 22 I.

30. Nelson Lichtenstein, "Class Politics and the State During World War Two", International Labor and Working-Class History, 58 (2000), pp. 26I-274, 26I.

31. Karl Polanyi, The Great Transformation: The Political and Economic Origins of Our Time (Boston, MA, I944), ch. I. 
possessed mechanisms for comprehensively controlling the economy, in the course of World War II, Western democracies had installed them as well (often even more effectively than the former). As a result, British children enjoyed better health at the war's end than at its beginning, workers' salaries were higher, and the sense of social justice was strengthened. ${ }^{32}$ In various countries, furthermore, World War II forged a culture of solidarity based on an ethos of shared sacrifices, helping to create the conditions that would make possible a broad, consistent political alliance that favored redistributive reforms. ${ }^{33}$ After the war, as Geoff Eley points out, "the major increments of general European democracy [...] depended on the prior conditions of societal breakdown or transformation produced by war". ${ }^{34}$ Rights expanded considerably in several waves as the state intensified its "demands upon society, its resources and territorial population". While the militarization of society had undoubtedly a top-down and authoritarian dynamic, at the same time, war produced "new democratic capacities, which became organized into an impressive postwar legal, institutional, and political settlement", and the war effort "legitimized the voice of all those groups willing to situate themselves inside the consensus", such as an organized working class, women, youths, and soldiers. These contradictions are succinctly communicated in the expression, "cashing in of the patriotic check"; in other words, "the popular expectation of substantial social and political reform in return for the sacrifices required by the wartime mobilization". 35

It is thus no coincidence that the impact of World War II on the working class in various parts of the world has become a recurring topic of debate, including a growing number of case studies for non-Western countries. ${ }^{36}$ For instance, Peter Alexander has compared the impact of the war economy on the interrelation between race and class both in the United States and in South Africa. In both countries, "as a consequence of war-related industrialization and resistance, black workers joined labour movements en masse. [...] [It] was a period of extensive industrial conflict and rising union membership" and "the working class was transformed, becoming larger, younger, blacker and more female". ${ }^{37}$ Both countries also similarly

32. Eric Hobsbawm, The Age of Extremes: The Short Twentieth Century, I9I4-I99I (London, 1994), p. 47.

33. Geoff Eley, Forging Democracy: The History of the Left in Europe, I850-2000 (Oxford [etc.], 2002), pp. $278-298$.

34. Idem, "War and the Twentieth-Century State", Daedalus, I 24:2 (1995), pp. I 55-174, I62.

35. Ibid., pp. 164, 165, I66.

36. See, for instance, the following two issues of International Labor and Working-Class History dedicated to these topics: "The Working Class in World War II", International Labor and Working-Class History, 38 (1990) and "Wartime Economies and the Mobilization of Labor", International Labor and Working-Class History, 38 (2000).

37. Peter Alexander, "South African and US Labour in the Era of World War II: Similar Trends and Underlying Differences", in Rick Halpern and Jonathan Morris (eds), American 
experienced increased participation in the labor market that strengthened activists' self-confidence, as well as accelerated inflation, which intensified the pressure for higher salaries and thus resulted in strikes, which were generally successful. Agreements between organized labor, the government, and employers, although intended to decrease the number of work stoppages, further stimulated unionization, which in turn fomented the spontaneous growth of movements focused on claiming rights. In both countries, although many workers were still full of racial prejudice, multiracial strikes took place, which generated a higher level of organization among black workers and a more egalitarian tendency among white workers. The differences between the two cases, however, are equally striking: In the United States, the Executive Order 8802 banned racial segregation in hiring practices, while measure 145 in South Africa reinforced racial divisions. In this process, organized labor in South African was severely weakened, and the possibility of attaining working-class, interracial unity in the post-war period was substantially reduced.

Latin America's involvement in World War II was of a nature and intensity absolutely distinct from that of the main belligerent nations. While military conflicts have, in general, played a less important role in the formation of nation states in the region than in other parts of the world, ${ }^{38}$ the subcontinent at first sight seems to have been peculiarly detached from the twentieth century's great wars: Latin America has not experienced the "gigantic catalyst" of the two world wars, which, in Europe, "radicalized unpolitical workers, multiplied trade union members, lifted working-class parties into office, unleashed social revolutions". ${ }^{39}$ This manifested itself also in the way these have been rendered in public space: Despite Brazil's participation in World War II, "even in I945, there appears to have been little effort to glorify" the Allied victory. ${ }^{40}$

The South African example mentioned above, however, suggests that the war effort can be important even for workers from countries with little or no involvement in combat. In her book on Chilean coal miners, Jody Pavilack demonstrates how World War II marked the high point of both the process through which workers conquered their rights and of their assertion as political protagonists, a process that had already been developing

Exceptionalism? US Working-Class Formation in an International Context (New York, 1997), pp. 244-270, 261.

38. This refers to wars between nation states. The picture changes dramatically if armed internal conflict, civil wars, anti-colonial mobilizations, and the internal colonization campaigns against indigenous populations are included.

39. Perry Anderson, "The Common and the Particular", International Labor and Working-Class History, 36 (1989), p. 3 I-36, 35 .

40. Miguel Centeno, Blood and Debt: War and the Nation-State in Latin America (University Park, PA, 2002), pp. 86-87. 
under the Popular Front governments since the beginning of the I930s. This more leveled interaction between workers and representatives both of capital and the state manifested itself in a unique political conjuncture, in which ideological polarization between capitalism and communism temporarily became less important in the face of the conflict between the Allied and the Axis forces. ${ }^{4 \mathrm{I}}$ Pavilack exemplifies this spirit of Peoples Front anti-fascism in recounting the US Vice President Henry Wallace's speech in Lota, a mining city known as a communist stronghold, hailing the local workers and their leaders as "soldiers of democracy". ${ }^{42}$ In Brazil, this profound change in the correlation of forces played out as well, although under the specific conditions of an authoritarian, corporatist regime.

\section{INTERNATIONAL RELATIONS, INDUSTRIALIZATION AND SOCIAL RIGHTS: BRAZILIAN WORKERS AND WORLD WAR II}

Brazil entered World War II at a relatively late stage, joining the Allies in August 1942 (before that, it had itself declared neutral). It contributed to the war effort with 25,000 soldiers sent into combat in Italy, of which $47 \mathrm{I}$ died. ${ }^{43}$ In addition, I,074 died when German submarines torpedoed ships off the Brazilian coast. The importance of Brazil's war involvement, however, goes beyond these numbers (which, compared to the death toll of the conflict as a whole, are miniscule): it produced transformations that would co-shape the course of the country's history in the second half of the twentieth century.

In an analysis of the international situation prepared by the Brazilian Minister of Foreign Relations, Oswaldo Aranha, for a secret meeting between the Brazilian president Getúlio Vargas and Franklin Roosevelt in the Brazilian city of Natal in I943, one can find "a summary of Brazil's foreign and domestic policies in the following decades": The "secure and intimate cooperation with the United States" would be a condition for the development of sea and air power aimed at consolidating Brazil's military predominance in South America. This demanded the development of heavy and war industry, the stimulation of key industries for global post-war reconstruction, the expansion of railway and road systems, and an exploration of the country's reserves of combustible fuels. ${ }^{44}$

4I. Hobsbawm, The Age of Extremes, p. I43.

42. Jody Pavilack, Mining for the Nation: The Politics of Chile's Coal Communities from the Popular Front to the Cold War (University Park, PA, 20I I).

43. Approximately I 2,000 were injured during the war, and accidents or illnesses later caused two thousand more deaths.

44. Frank McCann, "Brazil and World War II: The Forgotten Ally. 'What Did You Do in the War, Zé Carioca?’”, Estudios interdisciplinarios de America Latina y el Caribe, 6:2 (I995), pp. $35-70,46$. 
This was a radically new scenario. In previous decades, those responsible for steering the Brazilian economy had sought in vain Washington's assistance in signing commercial agreements that would have enabled them to secure the foreign currency necessary for the country's imports as well as for investments needed to boost its industrial development. The sudden willingness to bestow the status of strategic ally on Brazil came only in 1940, when British intelligence convinced the North American authorities that the Germans, making use of the open sympathies of the Estado Novo for European fascism, could cross the Atlantic along Dakar-Natal line, establish bases in north-eastern Brazil, and foment a wave of pro-Axis coups d'état in South America. The Americans, however, not only intensified the Good Neighbor Policy (which had already been announced for the whole of Latin America in 1933 by Franklin D. Roosevelt in his inaugural address and had become ever more important with the prospect of a new major war, aiming at cultural, economic, and other forms of international cooperation in the Americas); they also planned "Operation Pot of Gold" a "preventive" invasion of 100,000 soldiers, which would be set in motion should negotiations with Vargas fail. ${ }^{45}$

German economic influence in Brazil had grown in the previous period. In the early thirties, the collapse of coffee exports, a basic source of foreign currency, had initially forced Vargas to order a sharp devaluation of the Brazilian currency. Between I 933 and I936, planned and controlled deficits as well as a series of other measures (a policy later summed up under the label "import substitution industrialization") led to average growth of eight per cent (I 3.4 per cent in the industrial sector). But both the United States and Britain condemned the new currency exchange rate, which differentiated between imports and the transfer of profits, and they made their renewal of credit conditional upon the "liberalization" of the Brazilian economy. By contrast, Nazi Germany offered Brazil a deal that attended to the interests of the agro-export and industrial sectors in a more balanced way. The "compensation marks" that the German economic Minister Hjalmar Schacht proposed in 1934 were deposited in accounts on behalf of the Banco do Brasil in the Reichsbank (the so-called AusländerSonderkonten Für Inlandszahlungen - ASKI), without the losses that would have resulted from the currency's conversion into US dollars. These compensation marks were then used to acquire machinery and supplies, as well as new armaments for the outdatedly equipped Brazilian Armed Forces, which, at the time, the United States refused to supply. Between I934 and 1939, German participation in Brazilian exports grew from twelve to twenty per cent, and the participation of the United States only from 2 I.2 
to 25.5 per cent, while British fell from 19.4 to 10.9 per cent. ${ }^{46}$ This had a lasting impact: Still in I94I, the US consul in Recife attributed the continuing sympathies in north-eastern Brazil for the Nazis to the memory of the "prosperity" and the "good times" the compensation marks had brought, which guaranteed favorable prices for local producers of commodities, in addition to access to the much sought after German industrial products. ${ }^{47}$ Local affiliates of German and German-Brazilian companies created "Germanophilic" networks throughout the country, fostered the development of local Nazi groups, and supported German commercial, political, and military espionage..$^{8}$ German clubs rivaled the British ones as spaces of elite sociability in numerous Brazilian cities. In 1936, the flags of Brazil and of the Third Reich waved on the cover of the magazine of the Deutscher Klub of Pernambuco. ${ }^{49}$

Meanwhile, relations with the United States took a turn for the worse in the context of the US recession of 1937. The situation began to change precisely with the beginning of World War II in I939 and the subsequent attempts by the US to gain Brazil as an ally. The Brazilian government continued their prior policy currency exchange controls, but this time without US opposition. On the contrary, a new agreement was made for the payment of Brazil's foreign debt and in 1940, the "Inter-American Coffee Agreement" was established which set quotas for Brazilian coffee. In I942, the Washington Accords extended the policies of such quotas to a range of other Brazilian products including rubber, cocoa, cotton, Brazil nuts, iron ore, industrial diamonds, mica, quartz, jute, castor beans, etc., many of which had never been exported before. The economic rapprochement also meant a renewed increase in the importation of manufactured goods from the United States, while simultaneously new opportunities for Brazilian industrial growth arose in the context of the commercial blockade with Europe. Vargas exploited the global conflict to initiate the construction of the Volta Redonda Steel Plant (Usina Siderúrgica de Volta Redonda), allowing Brazilians to imagine turning their country, home of the largest iron ore reserves in the world, into a great steel producer. During its period

46. Marcelo de Paiva Abreu, "The Brazilian Economy, 1930-1980", Leslie Bethell (ed.) The Cambridge History of Latin America, vol. 9: Brazil since 1930 (Cambridge, 2008), pp. 283-393, 302.

47. Walter J. Linthicum (American Consul) to Jefferson Caffery (American Ambassador), I I February 194I, National Archives and Records Administration (Washington, DC) [hereafter, NARA], Record Group 84 - Records of the Foreign Service Posts of the Department of State [hereafter, Record Group 84], Entry 2 I 54, Political Reports, compiled I938-1949 (Recife), Box I. 48. Stanley Hilton, Suástica sobre o Brasil. A história da espionagem alemã no Brasil, 1939-1944 (Rio de Janeiro, 1977).

49. Walter J. Linthicum (American Vice Consul) to the Secretary of State, "Political activities in North-eastern Brazil”, Recife, I 3 February 1942, NARA, Record Group 84, Entry 2 I 54 , Political Reports, compiled 1938-1949 (Recife), Box I. 
of neutrality in the war, Brazil had discussed this project with the Germans, but the Allied blockade of the Atlantic since 1939 made such a partnership unviable. The United States refused to invest directly in the enterprise and to assume its management, as Vargas had wanted, but they offered decisive US financial and technical support for the creation of the plant as a state company. $^{. \circ}$

After the accords of 1942, supplying wartime demands generated an average growth rate of 6.4 per cent until 1945 , with industry growing at a rate of 9.9 per cent per year. The state's room for maneuver was strengthened with the increase in tax revenues from both consumer goods and income, in addition to the emission of the War Bonus. The accumulation of foreign reserves made possible a definitive negotiation of Brazil's foreign debt in I943, with a reduction of fifty per cent of its nominal value. The state assumed control of waters, minerals, and strategic industries, banks, and the insurance sector. Companies and properties belonging to the Axis governments were expropriated, including the powerful German and Italian banks. The Itabira Iron Company, founded by British investors in I9I I and the cause for long-drawn conflict with Brazilian authorities, became the state-owned and run Companhia Vale do Rio Doce. Meanwhile, the United States financed the construction of the railway connecting the gigantic iron mines of Itabira to the port of Vitória, capital of the southeastern state of Espírito Santo. Other state industries created during that period include the Companhia Nacional de Álcalis ${ }^{51}$ and the Fábrica Nacional de Motores. ${ }^{52}$ The management of the economy grew stronger with the creation of the Department of Public Administration (Departamento de Administração Pública), which modernized the budgetary system, of the Technical Economic and Finance Council (Conselho Técnico Econômico e Financeiro), and the Economic Mobilization Planning Commission (Coordenação de Mobilização Econômica). In the social policy realm, this was also a period that saw the creation of a body of labor regulations, most importantly the Consolidação das Leis do Trabalho in 1943 (Consolidation of Labor Laws) forging a coherent body of labor legislation out of the accumulated stock of previous regulations, the consolidation of a labor court system (Justiça do Trabalho), and the foundation of the Institutos de Previdência Social responsible for social security programs.

Relations with the United States, however, were rapidly changing. In I943, once an Allied victory was assured, the United States proved to be less generous. While the local costs of coffee production were rising, the US resisted further

50. De Paiva Abreu, “The Brazilian Economy”, p. 31 3; Dinius, Brazil's Steel City, ch. I.

5. See one of the classics of the I970s developmentalist literature: Octavio Ianni, Estado e planejamento econômico no Brasil (Rio de Janeiro, 2009 [197I]), pp. 24-32.

52. For the Fábrica Nacional de Motores with an emphasis on workers' struggles: José Ricardo Ramalho, Estado-patrão e luta operária. O caso FNM (São Paulo, 1989). 
readjusting the price. Also, Brazil's protectionist rationing of imports in 1944 generated new waves of discontentment within the Alliance. On the political scene, Vargas's relationship with the US had been deteriorating at an accelerating pace, and the ambassador Adolf Berle would come to play a relevant role in the fall of the Brazilian dictator. The experience of a nationalist political project in alliance with the US, however, would have long-term consequences - Brazil, in that regard, was no exception on the subcontinent with many HispanoAmerican countries taking a similar path since the I930s (although with different political regimes and varying degrees of assertiveness vis-à-vis the US). The nature of war would definitively strengthen the link between industrialization and national sovereignty. In Brazil, Vargas's "nationalist bargain" between the Axis and the Allies established a general orientation that sought to advance industrialization as the strategic objective and that would guide Brazilian foreign policy, then and for the next fifty years; this approach to foreign relations remained in force even through the great variety of different political regimes that characterized the second half of the twentieth century in Brazil..$^{53}$

But just how did Brazilian workers experience this period of accelerated changes? To what extent were the connections between defense, foreign policy, economic policy, and conceptions of citizenship, which have been observed in other contexts, also present in Brazil? Comparing Brazil in I940 - ten years after Vargas came to power - with what happened in this period in various parts of Latin America ${ }^{54}$ makes evident the fact that neither the state, nor political parties or working-class movements in Brazil achieved the mass mobilization necessary to provide the regime with an organic political support. In the absence of an integrated nationwide organization, those Vargas supporters who were part of the labor movement did not play any significant role in the political system. Even the era's social and pro-labor legislation was fragmented and was often not complied with. The onset of the Estado Novo dictatorship under Vargas in 1937 further exacerbated this situation, since the labor unions, now rid of communists, suffered a severe loss of both members and effectiveness, given the

53. Ricardo Seitenfus, O Brasil de Getúlio Vargas e a formação dos blocos, 1930-1942. O processo do envolvimento brasileiro na II Guerra Mundial (São Paulo, 1985); Frank McCann, The Brazilian-American Alliance, 1937-1945 (Princeton, NJ, 1974); Ricardo Seitenfus, O Brasil vai a guerra. O processo do envolvimento brasileiro na segunda guerra mundial (Barueri, 2003); Paulo Vizentini, Relações internacionais do Brasil. De Vargas a Lula (São Paulo, 2003).

54. The incorporation of the organized working class into the political system, combined with the active role of state regulation in working conditions, had seen its first beginnings in several Latin American countries during and after World War I, yet the most important advances were made since the I930s (but not without some shifts and reversals). For suggestive studies on three major countries (Argentina, Mexico, and Chile), see: Juan Carlos Torre, La vieja guardia sindical y Perón. Sobre los orígenes del peronismo (Buenos Aires, 1990); Kevin Middlebrook, The Paradox of Revolution: Labor, the State, and Authoritarianism in Mexico (Baltimore, MA, I995); Pavilack, Mining for the Nation. 
government supporters' organizational weakness. In other words, in comparative perspective, the Vargas regime in Brazil until the beginning of the I940s fell short of a major characteristic of Latin American populisms, namely the ability to mobilize or coopt a mass popular movement in support of the regime. 55

The perception of the importance of total war, however, changed the Estado Novo leadership's understanding of the relationship between civilian and military activities, which, in turn, reverberated in the realm of labor politics. Even without hostilities on its own territory and without a military commitment beyond the 25,000 strong Brazilian Expeditionary Force (Força Expedicionária Brasileira), this new kind of war resulted in the identification of civilian manual labor with national defense (the "soldiers of production"), ${ }^{56}$ generating contradictory dynamics that would bring both an assault on workers and important reforms in their favor. On the one hand, legislation geared toward economic mobilization, such as Law (Decreto-Lei) number 4639, passed on 31 August 1942, empowered the government to suspend labor and civil rights. ${ }^{57}$ On the other hand, though, the image of the factory as the trenches enabled workers to appropriate nationalist discourse as an instrument in their quest for better working conditions and pay. If workers sacrificed for the nation, they deserved a dignified life..$^{8}$ At the same time, rationing, scarcity, speculation, the black market, and so on stimulated popular revolt against the "sharks" that exploited the sacrifice imposed on the nation during wartime to gain extraordinary profits, strengthening class consciousness. ${ }^{59}$

55. For a comparative analysis of historical populisms in Latin America see the contributions to: Mackinnon and Petrone, Populismo y neopopulismo en America Latina.

56. On the militarization in Brazil during World War II, see, for instance, Fernando Pureza, "Economia de guerra, batalha da produção e soldados-operários. O impacto da Segunda Guerra Mundial na vida dos trabalhadores de Porto Alegre (1942-1945)" (MA thesis, Universidade Federal do Rio Grande do Sul, Porto Alegre, 2009).

57. On the impact of wartime labor laws and workers reactions, see Sílvio Frank Alem, "Os trabalhadores e a 'redemocratização' (Estudo sobre o Estado, partidos e participação dos trabalhadores assalariados urbanos e do pós-guerra imediato) I942-1948" (MA thesis, IFCHUnicamp, I98 I), chs I and II; Maria Celia Paoli, O trabalhador urbano na fala dos outros", in José Sérgio Leite Lopes (ed.), Cultura e Identidade Operária. Aspectos da cultura da classe trabalhadora (Rio de Janeiro, 1987), pp. 53-99; Joel Wolfe, Working Women, Working Men: São Paulo and the Rise of Brazil's Industrial Working Class, 1900-1955 (Durham, NC, 1993), pp. 94-I24, correctly argues that the militarization of labor limited even more the possibility that official labor unions might act as a mechanism for the representation of workers' demands in this period. He ignores, however, the possibilites that the aforementioned contradictory dynamics of anti-fascist nationalism opened up.

58. Hélio da Costa, Em busca da memória (Comissão de Fábrica, Partido e Sindicato no Pósguerra) (São Paulo, i 995), pp. I 5-20.

59. Paoli, "O trabalhador urbano", pp. 88-90. 
In parallel with these wartime labor politics, Brazil's productive demands and accelerated growth (as well as the demands of its US ally) unleashed waves of large-scale internal migrations: The acceleration of industrial production attracted rural workers to the city and workers from less industrialized regions to more industrialized ones. Thousands of men and women from Brazil's north-eastern region were recruited and drawn to the Amazon region to become "soldiers of rubber" ${ }^{\circ}$ Large masses of laborers migrated to uninhabited regions of the country, in which companies build large industrial plants like the aforementioned Usina Siderúrgica in Volta Redonda in the state of Rio de Janeiro, the Fábrica Nacional de Motores in Xerém, built in an area in the outskirts of the city of Rio de Janeiro called the Baixada Fluminense, as well as the Nitro Química in São Miguel Paulista, located on the periphery of the city of São Paulo, ${ }^{61}$ or the manganese mines in the Serra do Navio in the northern state of Amapá. ${ }^{62}$ Similarly, airports were built in Brazil's North and Northeast by the Airport Development Program, a project carried out by Pan American Airlines. ${ }^{63}$

An important reversal occurred, as well, with respect to conceptions of ethnic and racial hierarchies: German immigrants, who, until then, were seen as important contributors to the "whitening" of the country, became the greatest expression of the external ("the Axis") and internal ("a Fifth Column") enemy. As part of this process, the "imagined community" of the nation was redefined and centered around more "internal" sources, with policies that aimed toward the valorization of "popular culture", which, at the same time, were cleansed of its "disorderly" qualities. ${ }^{64}$

This "self-nationalization" of a society that, until recently, had celebrated the influx of a large numbers of European immigrants, among them a sizeable group of German-speakers, led to a series of conflicts and symbolical displacements: In Porto Alegre, for instance, which, at that time, was Brazil's third industrial pole, most industries were owned by Brazilians of German origin, generating a powerful association of ethnicity and class.

60. María Verónica Secreto, Soldados da borracha. Trabalhadores entre o sertão e a Amazônia no governo Vargas (São Paulo, 2007); on the debates inside the US government and Congress about the labor conditions and regulations in the wartime rubber production in the Amazon, see Seth Garfield, "A Amazônia no imaginário norte-americano em tempo de guerra”, Revista Brasileira de História, 29 (2009), pp. 19-65.

61. Paulo Fontes, Um Nordeste em São Paulo: Trabalhadores migrantes em São Miguel Paulista (1945-66) (Rio de Janeiro, 2008), pp. 89-I 3 I.

62. Adalberto Paz, "Os mineiros da floresta. Sociedade e trabalho em uma fronteira de mineração industrial amazônica (1943-1964)” (PhD dissertation, UNICAMP, Campinas, 201 I ), pp. 2 I-60.

63. Rebecca Herman, "In Defense of Sovereignty: Labor, Crime, Sex and Nation at US Military Bases in Latin America, 1940-1947" (PhD, University of California, Berkeley, 2014), p. 305, ch. II, "Labor Rights", Part 2: "Brazil", pp. I05-I 34.

64. Adalberto Paranhos, O roubo da fala. Origens da ideologia do trabalhismo no Brasil (São Paulo, I999), ch. II. 
This was not simply a matter of prejudice against what among German communities was seen as "Brazilian" workers (who bore last names of Portuguese origin and were associated with interracial unions with Indigenous or Afro-descended people). The institutional structure of the "German colony" (clubs, schools, newspapers, churches, the German consulate, and so on) amplified the influence of the German-Brazilian business owner on a broad spectrum of aspects of local social life. The ability to speak the language and ties with families of German origin might open doors for jobs in large companies with relatively comprehensive welfare schemes, as well as for their upward social mobility in and outside the factories. Brazil's entrance into the war had a profound impact on this local social arrangement. One symbolic indication of this shift was the popular reaction against the torpedoing of Brazilian ships by German submarines in August 1942: In Porto Alegre's industrial district, the street signs in "Germany" and "Italy" Avenue were pulled down by the crowd and substituted by other signs with the names of the two ships that had been sunk by German torpedoes. The act was later officially endorsed by a formal renaming of the streets by the city's mayor's office. Department stores that were part of the Renner chain, associated with the largest industrial complex in the state and an example of "welfare capitalism", were stoned. ${ }^{65}$

If Brazilian descendants of Germans were concentrated in the south, their presence in the country's economic activity also reached other regions, strengthened by the tightening commercial relationship between the two countries between 1934 and I 939. In Bahia, Dannemann and Suerdieck, two of the most traditional cigar factories in the interior of the state region (known as the Recôncavo, otherwise dominated by cane cultivation) were owned by "subjects of the Axis" (in fact, Brazilians of German origin). They also became the target of mass popular attacks after the sinking of Brazilian ships by the German navy. ${ }^{66}$ The largest industrial group in Pernambuco, Tecelagem Paulista, was owned by the Lundgren family, Swedish immigrants of German descent, who were under the powerful surveillance of domestic and international espionage because of their involvement with Nazism. As spokespeople for the north-eastern textile business world, in 1939 the Lundgrens, in a request to the authorities asking

65. Alexandre Fortes, Nós do quarto distrito. A classe trabalhadora porto-alegrense e a Era Vargas (Rio de Janeiro, 2004), ch. 5. That the sign of Avenida Italia was taken down simultaneously with the one of Avenida Alemanha allows for a second reading of the events: This popular action can also be seen as not targeting symbols of Germany per se but of the Axis powers and thus as driven in equal degree by a anti-fascist feelings.

66. See the eyewitness account of a worker of communist affiliation: João Falcão, O Brasil e a Segunda Guerra Mundial. Testemunho e depoimento de um soldado convocado (Brasília, I998), pp. $25-42$. 
for protectionist measures in favor of their industry, invoked the supposed racial inferiority of their workers as a main argument. It is worth quoting this at length as it seems representative of a language that was ubiquitous among Brazilian elites until the mid-r940s (and which would vanish from official discourse thereafter):

Among the populations of the North, primitive elements that entered into their amalgamation predominate - white, black, and indigenous, forming the so-called mameluco and mestiço [mixed] races, whereas in the South, because of the migratory movements, this has had a positive influence on the formation of Brazil's southern race. ${ }^{67}$

An ideology of racial supremacy was, of course, not limited to certain immigrant communities or those circles in Brazil that had sympathized with fascism or the Axis powers. As is well known, a racist prejudice against the ethno-racial composition of Brazil, especially the Afro-Brazilian population, was a cornerstone of positivism, the guiding ideology of the dominant elites since the abolition of slavery in I888, which also had numerous followers in the early labor movements: "Whitening" the country through European immigration in order to ensure "progress" was the outspoken and tacit consensus among the propertied classes, state elites, and many immigrant communities. ${ }^{68}$ In contrast, the war indeed redefined discourses concerning racial relations and their connections with class relations in Brazil. It marked the beginning of a new ideological framework replacing the old positivist ideas with the new image of Brazil as an essentially "mixed" nation that has constituted as a "racial democracy" and achieved harmony among the different groups. One of the major intellectual originators and advocates of this turn was the sociologist Gilberto Freyre (1900-1987), who, in his 1933 work Casa-Grande e Senzala (The Masters and the Slaves), boldly affirmed the Afro-Brazilian culture, at the same time painting an image of complementary symbiosis among the different groups of Brazilian society. ${ }^{69}$ It is thus indicative of the shifts in the mid-I 940 os that Freyre, after publishing an article in this vein in 1942, was arrested by two police officials who were "openly sympathetic with the Axis". In his piece, Freyre denounced the "falsely religious" people who dedicated themselves to spreading "ferociously ethnocentric, anti-Christian, and anti-Brazilian doctrines", ${ }^{\circ}$ and he concluded:

67. Cited in José Sérgio Leite Lopes, A tecelagem dos conflitos de classe na "cidade das chaminés" (São Paulo, I988), p. 295.

68. Jerry Dávila, Diploma of Whiteness: Race and Social Policy in Brazil, 1917-1945 (Durham, NC, 2003).

69. Gilberto Freyre, The Masters and the Slaves (Casa-Grande E Senzala): A Study in the Development of Brazilian Civilization (New York, 1946).

70. The "falsely religious" were former Franciscans from Germany who had been responsible for the Nazi propaganda coming out of precisely the Paulista Textile Company (Companhia de 
In an era in which forms of political hatred and racial pride are superimposed on top of everything else, even forcing the religious to break with their fidelity to the Christian ideas of human fraternity, peoples, like the Brazilians, whose entire organization is built on racial mixing, concerning the rights of the black, indigenous, and mixed-race people to the same privileges as whites, one has to be vigilant. $^{71}$

The emerging new consensus about racial relations enabled the Vargas regime to draw closer to a fundamental ideological component of a populist regime: the invocation of "the" people as a broad group of society that embodies the national idiosyncrasies and presupposes equality among each of the groups' members. To become effective, the regime thus had not only to include workers into the political project but also undo (or at least pretend to undo) the color line.

\section{POPULISM BY FORCE OF CIRCUMSTANCES?}

One major aspect of populism remains its mobilizational character mobilizations that give a populist leader much of his legitimacy and power, and which this leader should, ideally, be able to control. As mentioned, the Vargas regime since the "Revolution of 1930", yet especially during the Estado Novo since 1937, had conspicuously lacked this mobilizational component. However, as mentioned above in relation to the renaming of streets in Porto Alegre, popular mass action driven by nationalist sentiments, with the support (or at least the complacent tolerance) of sectors of the state apparatus, started precisely with Brazil's involvement in World War II. Being then a novelty in the Brazilian political scene, at least on a national scale, these anti-Axis mass actions multiplied throughout the country, especially after 17 August 1942, when the U-507 German submarine sank various sea vessels off the Brazilian coast resulting in $55 \mathrm{I}$ deaths. In a limited way, this also resulted in a sensible ideological shift in the Estado Novo from exhibiting philo-fascist tendencies towards a kind of

Tecidos Paulista). See a Brazilian secret police report filed in the reports by the US consul in Pernambuco: "Secretaria de Segurança Pública. Denúncia sobre supostas atividades de religiosos estrangeiros em Pernambuco. Diligências da Delegacia de Ordem Política e Social para esclarecimentos", in NARA, Record Group 84, Entry 2 I 54 (Recife: - Political Reports, 1938-49), Box I. Curiously, in November 1942, twenty-three of the forty-seven German employees of the company were detained by the political police and sent to a prison camp built by that same company sixty kilometers away from Recife, where they were held until August of 1945 - a company whose owners had shown to be heavily involved with Nazism. See Priscila Perazzo, Prisioneiros da guerra. Os "Súditos do eixo" nos campos de concentração brasileiros (1942-1945) (São Paulo, 2009), pp. I I 2-I 32.

71. Gilberto Freyre, "O exemplo de Ibiapina", in idem, Diário de Pernambuco, i June 1942. Quoted from a clipping of a newspaper article filed among the reports of the US consul in Pernambuco, in NARA, Record Group 84, Entry 2154 (Recife: - Political Reports, 193849), Box I. 
anti-fascist nationalism. While much of this was tokenistic from the state's side it did open some opportunities for left-wing activists. Communist militants recount that the campaign in favor of Brazil's entrance in World War II helped break the left's isolation in the national political realm after the intense waves of repression in 1935 and $1937 .^{72}$

As this article aimed to illustrate, Brazil's involvement in World War II helped to trigger a series of economic, political, social, and cultural changes. While historians studying post-I930 labor history have always converged on the years I94I-I945 - not least because of the consolidation of Vargasera labor laws and the emergence of a new kind of working-class political participation - the impact of World War II on the Brazilian working class has only been studied in depth more recently. In these more recent studies, three concerns have attracted the attention: First, the changes that the war produced in the articulation of class and inter-ethnic relations. Second, the changes that the evolution of Brazil's involvement in the international conflict engendered among the political forces vying for the support of the growing numbers of urban workers in the country. Third, the connections between, on the one hand, the conflicts among the top hierarchy of Vargas's Estado Novo as Brazil moved toward declaring war against the Axis, and on the other hand the adoption of a more proactive policy of expanding workers' entitlements to the rights of citizenship.

This article has argued that, in order to fully understand the impact of World War II on the Vargas regime and its relation to labor, it is necessary to take the full range of processes into account. In this way, it becomes clear how total war was a powerful force of change, even in a country with no hostilities on its territory (and only some at its shores) and a relatively small military commitment: Economically, World War II enabled the regime to become part of the Allied war machinery, producing a series of highly valued raw materials and crops under relatively favorable conditions, at the same time initiating a program of further industrialization and seeing the local consumer industry expand. Socially, this led not only to the wellresearched further inclusion of workers and the expansion of rights and legal regulations of labor, but also to momentous processes of internal migration, restructuring, and swelling the urban working classes. The corporatist arrangement already installed in the I930s was thus strengthened and expanded. Culturally, it led to a certain re-shuffling of the ethno-racial hierarchies in Brazil, resulting in a symbolical move away from previously

72. The metal worker Eloy Martins, for instance, describes his shop-floor activism in the state workshops in Porto Alegre, recalling the collective reading of news from the war that took place after lunch: "Our work was so efficient that, as soon as the party became legal, we were able to build a cell with more than twenty sympathizers. The machine operator, who was an intransigent defender of Hitler, became a sympathizer of the socialist cause". Eloy Martins, Um depoimento político (Porto Alegre, 1989), pp. 72-73. 
valued groups such as German immigrants, and the revaluation of Brazil as an essentially mixed nation of mestiços. Politically, meanwhile, Brazil's involvement in the war conditioned and enabled a mobilizational dynamics which was novel in Brazilian politics and which moved the Vargas regime which had since I 930 been a "populism sui generis" without the systematic invocation or mobilization of the masses - closer to other populist regimes in Latin America, such as Peronism in Argentina or Cardenism in Mexico.

The notion of populism has justifiably been criticized as problematic because of its analytical vagueness and its negative connotations. However, the critical and revisionist response - to dispose of the notion altogether and to use trabalhismo in order to highlight processes of inclusion and entitlement, which took place in Brazil especially since the mid-r940s, has its own limitations: It tends to over-emphasize idiosyncratic specificities, it ignores transnational and global influences, and, above all, it mistakes a central component, trabalhismo, for the whole. This whole - for want of a better term, it remains useful to call it populism - only becomes fully comprehensible if other domains are included in the analysis, such as geopolitical constellations, inter-ethnic relations, ideological shifts, yet above all the incorporation of mass mobilization, under the aegis of nationalism, as an intrinsic part of politics. Of course, the role of workers and popular classes in this process should never be underestimated (and indeed has been pointed out in a series of excellent studies). At the same time, in Brazil an apparently "external” process, World War II, equally played a central role. It helped to push a regime that previously had tended to shy away from such a kind of politics towards actually adopting "populism". In this way, populism as a political system in Brazil was born during the conjuncture of the World War II. 